\title{
ANDREI SHLEIFER \\ ON GOVERNMENT: A REJOINDER
}

\author{
WALTER BLOCK*
}

Although Shleifer himself might not interpret his paper (1998) as an unwarranted and gratuitous attack on philosophical anarchism, that is precisely its thesis, as shall be demonstrated below.

This author starts off by noting that, at least compared to the views espoused by the leading economists of the $20^{\text {th }}$ century compared to the decades at its close, opinion has shifted in the direction of less and less government participation in the economy. However, his $(1998,134)$ treatment is marred by characterizing Hayek (1944) and Simons (1948) as advocates of free enterprise. They were, instead, advocates of moderate socialism (Block, 1996, 2002). And this is nothing compared to Shleifer's (1998, 135) citation of Samuelson's (1948) description of the «free enterprise system» as one of «tremendous vitality.» Skousen's (1997) read on Samuelson is far more apt. Skousen finds Samuelson with his pants down around his ankles in the latter's comparison of the economic systems of the U.S. and U.S.S.R., where this Nobel Prize winning economist (in 1970) ${ }^{1}$ expects the latter to catch and surpass the former.

What, then, is Shleifer's thesis? He states $(1998,135)$ : «This paper beings by evaluating the case for in-house provision of goods and services by employees of a benevolent government. It argues that the conditions under which government ownership is superior in a country with good contract enforcement are very

* Harold E. Wirth Eminent Scholar Endowed Chair and Professor of Economics. College of Business Administration, Loyola University New Orleans. 6363 St. Charles Avenue, Box 15, Miller 321, New Orleans, LA 70118. c.v.: http:/ / www.cba.loyno.edu / faculty.html . Office: (504) 864-7934. Dept: (504) 864-7944. Fax: (504) 864-7970. Email: wblock@loyno.edu. http://www.WALTERBLOCK.COM

${ }^{1}$ http://nobelprize.org/economics/laureates/ 
limited, and involve particular cases where soft incentives are extremely valuable and competition is very limited.» We begin to get the hint, though, that for this author the question is not really one of government or private provision of goods and services. Rather, the often explicit and always implicit assumption is that government must be in control of theoretically all decisions in the market, and the only real question is whether government should do the actual provision, or, under its total and complete supervision and control, sub contract the actual work to the so called "private» sector. It is as if we are in the last days of the U.S.S.R., or Castro's Cuba or North Korea, and it is a given that the government should remain in overall control. The only issue is whether this continued management should be exercised in the same old way, by government itself, or, should we turn over a new leaf and allow private firms to achieve «social goals» as articulated by government, through contracting out the actual work to private entrepreneurs.

In Shleifer's (1998, 135, emphasis added) own words: «This perspective also helps to identify the opportunities for achieving social goals through private supply by a firm that may operate under a government contract or regulation. In a sense the issues here are closely related the vertical integration literature... except the question is that of the "make or buy" decision by the government rather than by a private firm.»

This «make or buy» choice on the part of the government is no mere rhetorical flourish. ${ }^{2}$ Shleifer is deadly serious when he limits his scope to government control, exercised either explicitly by itself ${ }^{3}$ or implicitly, through contracting out to private enterprise. Consider the following (Shleifer, 1998, 136):

If the government knows exactly what it wants the producer to make, then it can put its wishes into the contract (or a regulation) and enforce this contract. In this case, the difference between inhouse provision and contracting out disappears. Take some

2 For a dramatic critique of «achieving social goals through private supply» see Rothbard (1961).

${ }^{3}$ Courtesy of taxes mulcted from the public, of course. 
obvious cases where this point is crucial. A common argument for government ownership of the postal service is to enable the government to force the delivery of mail to sparsely populated areas, where it would be unprofitable to deliver it privately... From the contractual perspective, this argument is weak. The government can always bind private companies that compete for a mail delivery concession to go wherever the government wants, or it can alternatively regulate these companies when entry is free. It cannot be so difficult to write the appropriate contract or regulation; after all, the government now tells the U.S. Postal Service where it wants the mail to be delivered.

How would the full free enterprise system, as opposed to the one espoused by Shleifer, function in such a context?

Simple. There would be complete separation not of state and religion, but rather of government and mail delivery. ${ }^{4}$ Entry would be entirely free, not in the sense of costless, but rather that no one would be legally barred from entering the industry. Anyone could deliver the mail: Pony Express, Wells Fargo, the Spooner Mail Delivery Company, ${ }^{5}$ Acme, Walmart, anyone. Government would have no more to say any aspect of the functioning of this industry than it now has regarding paper clips or rubber bands. Even less, since in a pure free enterprise society there would be no labor laws, taxation, monetary policy, etc., all of which presently impact paper clips and rubber bands.

Moreover, the state would renounce its «social goal» of promoting mail service to the boon docks of the nation. People who wanted to locate in these out of the way places would have to pay the full (marginal) costs of their geographical choices. This is precisely what occurs regarding groceries, toys, gasoline,

4 The U.S. Constitution allows for governmental delivery (or, presumably, a la Shleifer, contracting out to private enterprise of this service), but does not require it. We read there: The Congress shall have Power... To establish Post Offices and post Roads (http://caselaw.lp.findlaw.com/data/constitution/article01/). Even if this document did require post office socialism, there is something of more import that that mere piece of paper: the rights of people to freely engage in enterprise.

5 http:/ / www.fee.org/vnews.php?nid=5002; http:/ / www.hazlitt.org/spotlight / 9901.html; http://www.neo-tech.com/businessmen/part7.html; http://www.cato. org/pubs/journal/cj15n1-1.html 
washing machines, etc. Those who locate on the periphery of the economy themselves pay for the additional delivery costs necessitated by their geographical decision-making.

As against that, there is an important consideration: the marginal revenue product of labor is typically higher in these outlying districts than elsewhere. In order to entice workers to live in the wilds, say, of Alaska, the wages must be proportionately higher, in conformity with the higher productivity that takes place there. This is why denizens of such places are able to pay for eggs, orange juice, computers, none of which are produced there, all of which must be transported there, at usually great expense. If these people are able to afford higher prices groceries, electronic goods, etc., due to this phenomenon, why should it not be the same with postal service? ${ }^{6}$

Shleifer would appear to be ambivalent on the issue of government versus private provision of goods and services. He full well realizes at least some of the advantages of the latter. This author $(1998,137)$ says:

An owner of a postal business who invents a better way to deliver mail can implement this innovation and profit from it. In contrast, if the government or someone else owns the business, the inventor needs the agreement of the owner to implement the innovation, and thus must share the benefits of the invention with this owner. Without the bargaining chip provided by ownership, the incentives to invest and innovate are lower... When assets are publicly owned, the public manager has relatively weak incentives to make either of these investments, because this manager is not the owner and hence gets only a fraction of the return.

And yet, he pretty much takes it all back with the following $(1998,137)$ : «With perfect contracting and regulation there is of course no difference between state and private provision of goods and services.» If there really is no difference between state and private provision, this means that the supposed advantages of the latter somehow disappear.

${ }^{6}$ For more on the case for privatizing the post office, see Adie, 1990, 1988, 1990; Butler, 1986; Moore, T., 1990; Moore, S., 1987; Priest, 1975. 
Now I am of course not interpreting Shleifer as maintaining that there is any perfection in governmental contracting with, or regulation of, private firms; and that therefore the incentive advantages ${ }^{7}$ he mentions of the latter over the former disappear. No one could believe that. My point is a different one. It is that incentives are not the only thing that matters in this deliberation between private and public provision of the goods and services under discussion. Far from it.

The advantages of the market vis a vis socialism not recognized by Shleifer stem from the Austrian side of the calculation debate with the socialists. Without private property and private firms, there can be no markets; without markets, there can be no market prices; without market prices, there can be no such thing as rational economic calculation, or rational economic planning. The U.S.S.R. lasted as long as it did only because it had access to western market prices. Without this window, the communist experiment would have dissolved in a bout of calculational chaos long before. One bit of historical evidence for this claim is that in the era of pure communism, approximately 1917-1920, while the Soviets did have access to western prices, they ignored them. Things went awry so quickly and radically that even the rabid followers of Marx agreed to some semi market reforms during the New Economic Plan, starting in 1921 (Boettke, 1990).

Shleifer $(1998,137)$ creates a hierarchy, with the public manager at the bottom because «he is not the owner and hence gets only a fraction of the return,» which accounts for his «relatively weak incentives... to improve quality or innovate... In contrast, private regulated contractors have much stronger incentives because, as owners, they get more of the returns on the investment.» But where oh where is the fully private firm owner in this hierarchy? Nowhere, that is where. He simply does not appear in the worldview of Shleifer.

7 Shleifer pretty much limits his appreciation of markets, such as it is, to the benefits of private vis a vis public sector incentives. But advocates of free enterprise have pointed to even more important considerations in this regard. For example, Hayek (1945) focuses on information flows, and Mises (1981) on the importance of freely derived prices as essential for economic calculation and thus rationality. On the latter point see also Salerno (1993), Hoppe (1996). 
Yet a moment's thought will convince anyone other than a dyed in the wool advocate of dirigisme that the pure entrepreneur has even more of an incentive to «improve quality or innovate.» He bears the entire risk and reaps all the rewards. In addition, he need not so much as deal with the government bureaucrat in charge of the contracting out process. The former need not even contemplate bribing the latter, for one thing. For another, he need not put up with the additional transactions costs (Coase, 1960) created in such a manner. Shleifer writes as if the government has a comparative advantage in out sourcing. No such claim has any veracity. Rather, private firms that sink or swim based on their ability to, among other things, contract out work to subcontractors, do have such an advantage. When is the last time a government bureaucracy was forced into bankruptcy, or its minions suffered another other kind of person financial loss, due to outsourcing? Never, that is when. How, then, account for Shleifer's misplaced confidence in their ability to responsibly acquit such as task? A mind set focused on the benefits of socialism would appear to be one plausible explanation.

At last we arrive at a series of cases which for our author mitigates not against purely private provision and in favor of government outsourcing or outright ownership -this is because, for Shleifer, as we have seen, there is no such thing as pure private provision- but rather which favor outright government ownership vis a vis governmental contracting out to quasi (because ultimately under government control) private firms. He (1998, 138-139) states:

There is, however, a class of cases where the argument against government ownership is not as straightforward. In these cases, cost reductions for which private suppliers have stronger incentives have potentially deleterious effects on the non contractible quality. For example, private prisons might abuse prisoners by hiring cheaper guards and failing to train them, private hospitals may refuse to treat patients on whom hospitals generally lose money, private schools might substitute less effective teacher's aides for more expensive teachers, and so on. In such situations, strong incentives may lead to inefficient outcomes or, put differently, the efficient producer might need to have soft 
incentives. Ironically, the government sometimes becomes the efficient producer precisely because its employees are not motivated to find ways of holding costs down.

My interests, it can readily be appreciated, do not lie in the comparison of A (government monopoly) with B (government outsourcing to «private» firms). Rather, they consist in the analysis of a comparison between A or B, it matters much not which, with $C$ (purely private provision). We shall, then, not follow Shleifer in his comparison of A and B in this regard. Instead, we will look at the previous quote from the perspective of $\mathrm{C}$.

Let us first attempt a reductio ad absurdum against it. Here, we repeat the above quote, but substitute private enterprises for his examples (in italics):

There is, however, a class of cases where the argument against government ownership is not as straightforward. In these cases, cost reductions for which private suppliers have stronger incentives have potentially deleterious effects on the non contractible quality. For example, private grocers might abuse customers by hiring cheaper guards and failing to train them, private restaurantteurs may refuse to serve poor diners, private auto makers might substitute less expensive rubber and metal for more expensive inputs, and so on. In such situations, strong incentives may lead to inefficient outcomes or, put differently, the efficient producer might need to have soft incentives. Ironically, the government sometimes becomes the efficient producer precisely because its employees are not motivated to find ways of holding costs down.

As we can see, Shleifer's argument "proves» far too much. With it, we can demonstrate that groceries, restaurants and automobile manufacturing ought to be nationalized. We are not limited to derogating B while elevating A; we can also dismiss C. But it is a given that $C$ is a viable institution, indeed, the only one that can fully satisfy customers in that no violence need necessarily accompany it (in sharp contrast to $A$ or $B$, which requires compulsory taxation, at the very least). Nationalizing groceries, restaurants and automobile manufacturing indeed! 
Yes, it cannot be denied, private prisons, hospitals and schools, ${ }^{8}$ might skimp and cheat and commit fraud. But what of it? The same applies to haberdashers, pizzerias and shoe stores. Should government take over all these private enterprises, either directly through ownership (communism) or indirectly through regulations and contracting out (fascism)? Of course not. The very idea is ludicrous. When then, should this apply to the industries mentioned by Shleifer? Our author vouchsafes us no reason for this course of action, apart from the possibility of fraud of various types and varieties. But as this threat afflicts the more mundane industries too (purveyors of ice cream, pizza, bicycles, Frisbees, etc.) and he does not call for such «remedies» in these cases, and he offers no relevant difference between the two sets of industries, he is logically precluded, or estopped (Kinsella, 1992, 1996) from doing so in the examples he mentions.

Moreover, there are market remedies for fraud, cheating corner cutting, etc., in groceries, restaurants, steel, clothing and all the rest. Outright fraud, of course, is a crime. As for the rest, the first line of defense includes rating agencies (Moody's, Standard and Poor, Universal Testing Laboratories), private certifiers (Good Housekeeping Seals of Approval, Kosher foods), brand names (McDonalds, Burger King and Wendy's, etc., stand ready to remove the franchise from any of their franchisees who serve bad food, do not offer clean rest rooms, etc.). Then of course there is plain old vanilla competition: firms that cut corners tend to go out of business, ceteris paribus, compared to those who continuously satisfy customers. This even applies to those in the tourist business, where repeat customers are not an every day occurrence. Disney World does not stay in business through skimping. Cruise ships advise their passengers as to tourist traps on the land. Why none of these institutions could work their «magic» with regard to prisons, hospitals and schools is not an objection that Shleifer chooses to address.

${ }^{8}$ For the case for private prisons, see Tinsley 1998-1999 and D'Amico, unpublished. For hospitals, see Barnett and Saliba, 2004; Hamowy, 1984; Herbener, 1996; Terrell, 2003. On schools, see Postiglione, 1982; Rothbard, 1971A, 1971B; Sowell, 1993. For the general case in favor of privatization of everything see Woolridge, 1970, Rothbard, 1973, Stringham, 2002. 
Amazingly, our author $(1988,139)$ pretty much admits all of this. He acknowledges that «customers can switch suppliers if they are dissatisfied with the service.» Further, he discusses «reputation building. If private suppliers want to have customers in the future, they are less likely to cut costs and reduce quality...» Why, then, does he not embrace the One True Faith of Free Enterprise? Because there is $(1988,139-140)$ «a rather narrow set of circumstances in which government ownership is likely to be superior. These are the situations in which: 1) opportunities for cost reductions that lead to non-contractible deterioration of quality are significant; 2) innovation is relatively unimportant; 3) competition is weak and consumer choice is ineffective; and 4) reputational mechanisms are also weak.»

But then, an accomplished broken field runner, Shleifer (1988, 140) reverses himself once again: the private non-profit sector can make good these profit oriented shortcomings. When all of these things are taken into account, Shleifer $(1988,140)$ opines that «the set of activities that are left for the government to perform under these circumstances is very limited but not empty. What examples does he offer? First, is the operation of Air Force One. Here, neither private for profit, nor yet non-profit service can suffice. He (1988, 140-141) states:

First, the security of the president of the United States is important enough that it is a bad idea to have a service provider who might shirk on the quality of the personnel, preparedness or service in order to reduce labor costs, or pick shorter and riskier routes to conserve fuel. Soft incentives when it comes to cost containment are essential. Second, ongoing innovation is probably not an important dimension of this particular service. Third, the president cannot readily decide to switch suppliers when his plane is not ready on short notice. Fourth, reputational considerations may not be significant enough to counter the concerns raised above. Finally, the incentives of a not-for-profit operator may still be too strong to contract out this service.

There are problems here. Why should POTUS be placed on a pedestal unfit for the Chief Executive Officer of Wal-Mart, U.S. Steel or Microsoft? In the very limited philosophy of government 
supposedly envisioned by Shleifer, the importance of the jobs undertaken by these latter worthies would exceed that of the CEO of the government. The country would likely be at peace, no continual stream of new laws would be continuously needed, his powers would be severely truncated back down to the level enjoyed by the first few presidents of the U.S. George Washington got along just fine without any airplane at all, let alone one run by government bureaucrats. Whose job is more important for the well being of the Swiss? Their president, who no one outside that country can even name, or the heads of its most important corporations? Some may say the former, but would have, at least, to concede it would be a horse race. It is so obvious that the CEO of Switzerland's largest bank should not contract out the operation of its private jet to a company that specializes in providing this sort of transportation? If private companies cannot be entrusted with important tasks, why is Haliburton supplying our troops in Iraq?

One other example is forthcoming $(1988,141)$ : «nationalization or heavy regulation in a war...» There are two problems here. First, the existence of a strong central government is likely to make war more likely, not less. The government, here, is hoisting itself up by its own petard. If not for its own existence, war would not likely arise. And yet it is only because of the war, which its own existence made more likely, that it is presumably justified in nationalizing or heavily regulating industry. ${ }^{9}$ Second, it is by no means clear that even in times of war governmental bureaucracy is more efficient that private enterprise. How, for example, does rent control, or price controls on factors of production, help allocate resources to their most efficient ends? Based on elementary economic analysis, the very opposite would appear to be the case. If the government wants, say, resources to be diverted from civilian cars and trucks to tanks and armed personnel carriers, it need not mandate a change relative prices nor compel

9 One of the causes of increased governmental size is the ratchet effect: during war, government control of the economy catapults in an upward direction. After it is over, government recedes, but does not reach its previous war time low. See on this Higgs, 1987. 
or forbid any other economic activity apart from raising taxes and purchasing transportation vehicles necessary for war. ${ }^{10}$

The next section of Shleifer $(1998,141-143)$ is his strongest. He relaxes his implicit assumption that government is motivated solely to promote the public interest (whatever that is) and looks at this institution through less rose colored glasses as it really functions: venal, corrupt, given to greasing squeaky wheels (e.g., the post World War II British coal miners) and the evils of full and outright communism.

But even here our author's adherence to the market is less than fully satisfactory. For example, he (1998, 143-144) states: "In an economy with weak institutions, it may be better to have totally private garbage collection than either garbage collection by government employees, or that by the private contractors who got their concessions by bribing officials. It may, for similar reasons, be better to have unregulated private schooling.» Yes, but why only in the case of "weak institutions»? This is to be sure indeed the case, but so is it when the economy has "strong" institutions, by which, presumably, Shleifer means there is little bribery and corruption. This is damning the market with faint praise. Free enterprise is to be preferred to a corrupt government, but a clean one better promotes economic welfare then does laissez faire capitalism. Sure.

It is time, it is past time, for us to better appreciate "corruption» in government. After all, if a law is unjust and inefficient, then violating it must have at least some merits, both from an ethical and economic point of view. If tariffs and quotas interfere with free trade, and given that the latter is welfare enhancing, then smuggling has positive virtues. Bribing a customs official maybe be corrupt de jure, but de facto it promotes the economy. The U.S.S.R. was plagued by all sorts of market interferences; violating them, e.g., corruption again, probably rendered the Soviet system less pernicious than it otherwise would have been.

10 It cannot be denied that higher taxes, nor, indeed, any level of taxation, is compulsory. But this is at least conceptually distinct from Shleifer's call for nationalization or regulation. 
Shleifer's (1998, 144-147) discussion of "private schooling» is marred by his equation with this phrase of «educational vouchers.» The latter are related to true private education as is market socialism to free enterprise. In a word, these are two very different things, and Shleifer's conflation of them does not spread light on this subject. The very opposite is the case. Right now, there is complete laissez faire ${ }^{11}$ with regard to things like paper clips, rubber bands, pens and pencils. There are no "vouchers» for any of these products. Suppose, however, that government were to begin taxing us for these items, and issuing us "vouchers" for them. Would anyone be so rash as to claim that free enterprise was now operating in this sector of the economy? Of course not. It is amazing that otherwise intelligent commentators would make so elementary a mistake when such a system applies to education.

Then, too, Shleifer $(1998,146)$ comes out swinging against voluntary segregation. But promoting a government scheme on the ground that it will reduce the effect of freely made locational choices on the part of the populace is equivalent to forced integration. Say what you will about reducing the scope of free association, it is difficult to see how this can be reconciled with private property rights and free enterprise. ${ }^{12}$ That Shleifer actually defends school vouchers is sufficient to characterize him as an enemy, not a friend, of capitalism; that in so doing he takes the side of forced integration only further buttresses this point. Of course, to favor coercive segregation, as was done in political jurisdictions in the south under Jim Crow legislation, is also incompatible with a regime of private property rights and free enterprise.

\section{BIBLIOGRAPHICAL REFERENCES}

Adie, D.K. (1988): Monopoly Mail: Privatizing the United States Postal Service, New Brunswick, N.J.: Transaction.

\footnotetext{
11 Well, as complete as it can get in a welfare state.

12 Hoppe (2001) goes so far as to equate free and open immigration with forced integration. We need not go all the way in this direction (Block, 1998, 2004, forthcoming; Block and Callahan, 2003; Gregory and Block, 2007) to realize that the latter is the antithesis of the free society.
} 
ADIE, A.K. (1990a): «Why Marginal Reform of the U.S. Postal Service Won't Succeed,» in Free the Mail: Ending the Postal Monopoly, Peter J. Ferrara, ed., Washington, D.C.: The Cato Institute.

- (1990b): The Mail Monopoly: Analyzing Canadian Postal Service, Vancouver: The Fraser Institute.

BARnetT, W. II and SAlibA, M. (2004): «A Free Market for Kidneys: Options, Futures, Forward, and Spot.» Managerial Finance. 30 (5): 38-56.

Block, W. and Callahan, G. (2003): «Is There a Right to Immigration? A Libertarian Perspective,» Human Rights Review. Vol. 5, N.․ 1, October-December, pp. 46-71.

BLOCK, W. (1996): «Hayek's Road to Serfdom,» Journal of Libertarian Studies: An Interdisciplinary Review, Vol. 12, ‥ 2 , Fall, pp. 327-350, http://www.mises.org/journals/jls/12_2/12_2_6. pdf.

- (1998): «A Libertarian Case for Free Immigration,» Journal of Libertarian Studies: An Interdisciplinary Review, Vol. 13, N.․․ 2, summer, pp. 167-186; http://www.mises.org/journals / jls/13_2/13_2_4.pdf.

- (2002): «Henry Simons Is Not A Supporter of Free Enterprise,» Journal of Libertarian Studies, Vol. 16, N. 4, Fall, pp. 3-36; http://www.mises.org/journals/jls/16_4/16_4_2. pdf.

- (2004): «The State Was a Mistake.» Book review of Hoppe, Hans-Hermann, Democracy, The God that Failed: The Economics and Politics of Monarchy, Democracy and Natural Order, 2001 May 25. http:/ / www.mises.org/fullstory.asp?control= 1522.

- (Forthcoming): «Hoppe, Kinsella and Rothbard II on Immigration: A Critique.» Journal of Libertarian Studies.

BoettKe, P. (1990): The Political Economy of Socialism: The Formative Years, 1918-1928, Boston, MA: Kluwer.

ButLER, S.M. (1986): «Privatizing Bulk Mail,» Management, 6, N.ำ 1.

COASE, R.H. (1960): «The Problem of Social Cost,» Journal of Law and Economics, 3: 1-44.

D'Aмico, D.J. (Unpublished): «The Role of Prisons in the Free Market». 
FERRARA, P.J. (1982): Social Security: Averting the Crisis, Washington DC: Cato Institute.

- (1985) ed.: Social Security: Prospects for Real Reform, Washington DC: Cato Institute.

Gregory, A. and BLOCK, W. (2007): «On Immigration: Reply to Hoppe.» Journal of Libertarian Studies, vol. 21, N. 3, Fall, pp. 25-42; http://mises.org/journals/jls/21_3/21_3_2.pdf Hamowy, R. (1984): Canadian Medicine: A Study in Restricted Entry, Vancouver: The Fraser Institute.

HAYEK, F.A. (1944): The Road To Serfdom, The University of Chicago Press, Chicago.

- (1945): «The Use of Knowledge in Society.» American Economic Review. Vol. 35, N.. 4: 519-530.

Herbener, J. (1996): «Socialized Medicine, Take Two.» The Free Market. Vol. 14, N. 7, July; http://www.mises.org/ freemarket_detail.asp?control=172\&sortorder=articledate Higgs, R. (1987): Crisis and Leviathan: Critical Episodes in the growth of American Government, New York: Oxford University Press.

Hoppe, H.H. (1996): «Socialism: A Property or a Knowledge Problem,» Review of Austrian Economics, 9 (1): 143-152.

KINSELLA, S.N. (1992): «Estoppel: A New Justification for Individual Rights,» Reason Papers N.. 17, Fall, p. 61.

KINSELLA, S. (1996): «Punishment and Proportionality: the Estoppel Approach,» The Journal of Libertarian Studies, Vol. 12, N.으 1, Spring, pp. 51-74.

Mises, L. VON (1981): Socialism, Indianapolis: Liberty Press/Liberty Classics.

Moore, S. (1987): «Privatizing the U.S. Postal Service,» in Stephen Moore and Stuart Butler, eds., Privatization, Washington: Heritage Foundation.

Moore, TH.G. (1990): «The Federal Postal Monopoly: History, Rationale, and Future,» Free The Mail: Ending the Postal Monopoly ed. Peter J. Ferrara.Washington, D.C.: CATO Institute.

Postiglione, G. (1982): «The Opponents of Public Education: New York State, 1870-1880,» The Journal of Libertarian Studies, Vol. VI, N. ㅇ 3-4, Summer/Fall, pp. 359-376. 
PRIEST, G. (1975): «The History of the Postal Monopoly in the United States,» Journal of Law and Economics, Vol. 18, N. 33, pp. 33-80.

Rothbard, M.N. (1961): «A Fable for Our Times By One of the Unreconstructed» http://www.lewrockwell.com/rothbard/ rothbard22.html

- (1971a): «Education: Free and Compulsory» (Part I). Individualist, April, pp. 2-8.

- $\quad$ (1971b): «Education: Free and Compulsory» (Part II). Individualist, July-August, 1971, pp. 3-16.

- (1973): For a New Liberty, Macmillan, New York.

SALERNO, J.T. (1993): «Mises and Hayek Dehomogenized,» Review of Austrian Economics, Vol. 6, ‥ 2, pp. 113-146.

Shleifer, A. (1998): «State versus Private Ownership.» Journal of Economic Perspectives. Vol. 12, N.․ 4, Fall, pp. 133-150.

SimONS, H.C. (1948): «A Positive Program for Laissez-Faire.» Economic Policy for a Free Society, Chicago, University of Chicago Press.

Skousen, M. (1997): «The Perseverance of Paul Samuelson's Economics,» Journal of Economic Perspectives, Vol. 11, N.ㄹ 2, Spring, pp. 137-152.

SOWELL, TH. (1993): Inside American Education: The Decline, the Deception, The Dogmas, New York: The Free Press.

Stringham, E. (2002): «The Emergence of the London Stock Exchange as a Self-Policing Club.» Journal of Private Enterprise, Vol. 17, N. 2, 1-19.

Terrell, T.D. (2003): «Socialized Medicine in America.» The Free Market. Vol. 23, N. 11 , November. http:/ / www.mises.org/ freemarket_detail.asp?control=458\&sortorder $=$ articledate

Tinsley, P. (1998-1999): «With Liberty and Justice for All: A Case for Private Police,» Journal of Libertarian Studies, Vol. 14, N.으 1, Winter, pp. 95-100.

Woolridge, W.C. (1970): Uncle Sam the Monopoly Man, New Rochelle, N.Y.: Arlington House. 